\title{
Historical Notes
}

\section{Concept of Manas in Sāṃkhya Darśana}

\author{
Hetal Amin*, Rohit Sharma**, H A Vyas*** and M K Vyas****
}

(Received 31 January 2013)

\begin{abstract}
Since time immemorial manas has been the subject of curiosity for scholars, scientists and philosophers. Vedic, Philosophical and Āyurvedic literatures have a vast and deep description of manas. Philosophers either 'āstika' or 'nāstika' have described manas siddhāñta vividly. Though these kinds of difference of opinions are there, all the darśana accept the importance of manas in the process of perception and even for the birth of any individual. Here, an attempt is made to highlight the concept of manas in sāṃkhya darśana.
\end{abstract}

Key words: Darśana, Sāṃhya, Manas.

\section{Introduction}

Since time immemorial manas has been the subject of curiosity for scholars, scientists and philosophers. The reason behind this curiosity is its importance in the development of mankind. Human being is superior to other creatures in the series of development. This Supremacy of man remains in his quality to work after thinking, which is the function of manas. No other animal is capable of thinking logically. This is the only reason which leads mankind to the crest of development in every aspect. Simultaneously manas is also responsible for many of the problems of present era. These problems may be political, environmental, social or personal. Considering this fact, WHO included psychological health in the definition of complete health, only a healthy mind is capable of overcoming these problems.
In Indian culture mind has been described by various angles. Vedic, Philosophical and Ayurvedic literatures have a vast and deep description of manas. In Samskrta, the word manas is derived from the root word 'मनस्' which means 'to know' and was used in this sense in early veda and other literature. In Yajurveda, the manas has been conceptualized as the inner flame of knowledge. It is said that all the indriya (sensory organs) are directly controlled by manas. Without the help of manas the process of perception can't take place. Rgveda also has description of manas. It has been clearly mentioned that purification of mind prevents occurring diseases in human beings; therefore one should have noble thoughts. The capacity of manas in healing process has also been described in Rgveda.

Mañdukya Upaniṣad described manas as a prime cause of birth and mokṣa (मनः एव मनुष्याणां

\footnotetext{
* Ph. D Scholar, Department of Basic Principles, IPGT \& RA, GAU, Jamnagar; Address: A/35, Geet-Gunjan Society, Harani Road, Baroda, Gujarat, India; E-mail: dr.hetal1985@gmail.com

** Ph. D Scholar, Department of Rasashastra and Bhaishajya Kalpana, IPGT \& RA, GAU, Jamnagar- 361008 ,

***Assistant Professor, Department of Basic Principles, IPGT \& RA, GAU, Jamnagar- 361008

****Associate Professor, Department of Basic Principles, IPGT \& RA, GAU, Jamnagar- 361008
} 
कारणं बन्धमोक्षयोः ।). In Kena Upanișada, importance of manas in perception is described through various examples.

Philosophers either 'āstika' or 'nāstika' have described manas siddhānta vividly. All darśana also described manas but there is difference in opinions regarding origination, properties and number of manas etc. For example, Nyāya and Vaiśeșika philosophies believe the manas to be kāran dravya i.e. an eternal substance, always remaining present in the universe. On other hand, sāmkhya philosophy believes that manas is not an eternal substance rather originates from sāttvika ahamkkāra during śrști kriyā (evolution of universe).

Though, these kinds of difference of opinions are there, all the darśana accept the importance of manas in the process of perception and even for the birth of any individual. Here, an attempt is made to highlight the concept of manas in Sāmkhya darśana.

\section{यतः सर्वपारिषदमिदं शास्त्रं, तेनायुर्वेदाविरूद्ध वैशेषिक सांख्यादि दर्शनभेदेन \\ विरूद्धार्थोऽभिधीयमानो न पूर्वापरविरोधमावहतीत्यर्थः।} च.सू. $8 / 3$ चक्र

In some cases, while dealing with certain concepts, the darśana may also show dissimilarity in opinion among them but, it is still accepted in grantha by Ācarya. Darśana thought begins from origin of this universe, and of Ayurveda also.

The word darśana is created from the root word “दृश” which stands for 'to see'. The other meaning of the word are looking at, observing, knowing and understanding. The scope of philosophy is extensive and wide spread. It includes all the efforts to accomplish and achieve the knowledge of all aspects. The beginning, development and destruction of universe are subject matter discussed in all branches of philosophy. Sāmkhya or the enumeration of the various cosmic principles (tattva), which are considered separate from the true self or consciousness (puruṣa)

The word sāmkhya is derived from the word "samkhya " which means a sense of thinking and counting. Here, thinking is with reference to some basic principles of knowledge of purușa and counting refers to the 24 principles born out of prakrti. This double implication of the word has been set forth by Vijñana Bhikṣu in his preface to sāmkhya -

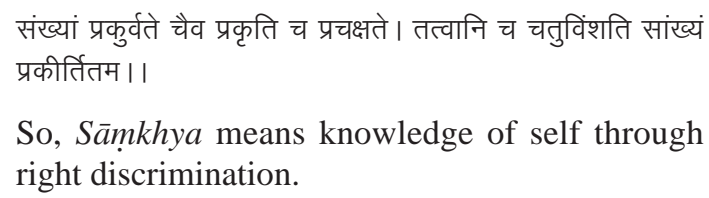

So, Sāmkhya means knowledge of self through right discrimination.

Sāmkhya is psychological system of Philosophy. It explains the evolution of the universe from the psychological perspective. It advocates that the 'mahat', an effect evaluated from 'prakrti' itself is manas (Ishwar, 1837, p.6; Sām. Kār. 1.3).

\section{Utpatti of Manas}

According to 'sāmkhya' system of philosophy, mahat, evaluated from prakrti, itself is manas and it is further one of the effects of ahamkāra (Sharma, 2000, p. 3; Sām. D. 1.7, 2.17) 'buddhi' (intellect), 'ahaṃkāra' (egoism) and 'manas' (mind) constitute the psychic apparatus of living personality. They are also called trividha añtahkarana (three internal organs).

To understand the origin of manas, one should have an overview of the cosmology of sāmkhya philosophy. According to sāmkhya, the universe has evolved from a primary principle called mūla prakrti. In the presence of purușa, the triguna (three attributes) are latent in prakrti purusa in a non-manifested state; hence, the kārya (effect) of the prakrti also contain these triguna (Ishwar , 1837, p.6; Sām. Kār. 1.3).

The characteristics of these attributes are explained in sāmkhya. Sattva is laghu in nature 
and it is the cause of prīti (happiness) and enlightens the prakāśaka (knowledge). Rajas are having the property of cala (movement) and it produces action. It is the cause of aprīti (aversion). Tamas is guru (heavy) and causes viṣa da (depression). Even though these three attributes are having opposing characteristics, they compare with the flame (sattva), oil (rajas) and wick (tamas) of an oil lamp (Ishwar, 1837, p. 13; S.Kār.12).

From the prakrti, i.e the avyakta (nonmanifest), the vyakta (manifested universe) is affected sequentially. The first effect from the nature is a conscious principle called Buddhi (intellect) or mahat (grossness). This intellect is undifferentiated and is just a notion. adhyavasāya (determination) is the characteristic feature of buddhi i.e. intellect (Ishwar, 1837,p. 21; S.Kār.23). Determination like "It is this", "It should be done" and "It should not be done", are coming under the purview of the intellect. By the predominance of the attributes, intellect exhibits eight featuresmerit, knowledge, detachment and prosperity are the features presented by sattva and demerit ignorance attachment and non-prosperity are the features presented by tamas.

From this undifferentiated intellect, a notion of 'I' ness is generated; this is a form of ahamkāra (ego) that exhibit possessiveness (Ishwar, 1837,p. 21; S.Kār.24). This ahamkāra (ego) differentiates itself into three according to the predominance of the major attributes, thus there are three types of egos namely sāttvika ahaṃkāra (virtuous ego), rājasika ahamkāra (active ego) and tāmasika ahạ̣kāra (inert ego).

Jñāneñdriya (sensory faculties), karmeñdriya (motor faculties) and sattva (manasmind) are evolved from the sāttvika ahaṃkāra (Ishwar , 1837, p. 22; S.Kār.25) (virtuous ego). But this evolution is assisted by rājasika ahaṃkāra (active ego). The sentient world is the effect of tāmasika ahamkāara (inert ego), this evolution also is assisted by rājasika ahamkāra (active ego), thus one find that manas (sattva) according to sāmkhya is the effect of sāttvika ahaṃkāra (virtuous ego), Nevertheless this ego contains the other two attributes too in a subdued state, Because of the inter-convertibility of the attributes, sattva may exhibit predominance of any of the attributes by the influence of favourable circumstances.

Prakrti (primordial nature) is not an effect; it is just a cause (Ishwar, 1837, p. 22; S. Kār 25). That is why it is called nature. Ahamkāra (ego), mahat (intellect) and tanmātra (five quanta of senses) are causes and also are effects. The eleven indriya (faculties) generated from sāttvika ahamkāra (virtuous ego) and the elements affected from the quanta are mere effects are not considered as causes as nothing new is affected from them. Thus, manas is just an effect not a cause.

\section{Guna of Manas}

Manas is considered as faculty as it has common origin with the other faculties. They all originate from various egos. Differentiation into various faculties is because of the peculiarity of evolution of the major attributes (Ishwar, 1837, p.27; S. Kār.27).

\section{Manas as Ubhayeñdriya}

According to Sāmkhya darśana, manas is considered as ubhayeñdriya (Sharma, 2000, p.23; Sam. D. 2.26). Manas is a dual faculty as it is working as sensory and motor organ too (Sharma, 2000, p.8; Sām. D.5.69). It is the instrument to gain its own object called vicārya (thinkable). Anything that can be thought of is thinkable. As a motor faculty it is instrumental to the actions done through sattva. It also helps sensory and motor faculties in their functions.

\section{Properties of Manas}

Manas is atomic, an instrument, a sense organ, always active, non morphological, hence is not vyāpaka (Sharma, 2000, p. 3; Sām. D.2.42). 
Manas is base for all samskāra (Sharma, 2000, p. 3; Sām. D. 2.40) helps in functioning of all other indriya (Sharma, 2000, p. 3; Sam. D.2.45). It is necessary to join $\bar{a} t m \bar{a}$ to manas and manas to indriya and further indriya to visaya for process of perception. Perceptive material of Indriya is converged and analysed with the help of manas hence it is super sense (Ishwar, 1837, p.27; S. Kār. 33).

\section{Manas as Karana}

Manas analyses the knowledge and actions so it is called the instrument for analysis (Sharma, 2000, Sām. D.2.26). Discrimination of the type, "This is like this and not like that" is done by manas. So sattva may be compare with the private secretary to the higher authority. Private Secretary collects the information from different sources and presents to the higher authority with notes on the merits and demerits of the matter to be implemented. Sāmkhya enumerates thirteen karana (instruments). From them ten are bāhya karana (Ishwar , 1837, p. 10; Sām. Kār. 6.25) (external instruments) and three are añtahakarana (internal instruments). The sensory and motor faculties come under the external instruments. Intellect, ego and manas are considered as internal instruments. Internal instruments have the ability to realize the past, present and future. External instruments can act only in the present. For example, one cannot perceive past or future with visual faculty whereas one can think of the past and future with sattva. Internal instruments are more important than the external instruments.

\section{Jñānotpatti Prakriyā}

The condition in which manas stays away from objects is known as dhyān (Sharma, 2000, p. 3; Sām. D. 1.58). With absence of aviveka (inability to analyse or differentiate) the further process of jñanna proceeds to the ultimate truth (Ishwar, 1837, p.26; S. Kār. 30). Perception of knowledge and execution of action may occur in two ways-simultaneous and sequential (Ishwar, 1837, p. 31; Sam. Kār. 2.45). In simultaneous perception and action; the intellect, ego, sattva and faculty are engaged simultaneously resulting sudden perception or action. In sequential perception and action faculties; sattva, ego and intellect work sequentially. This gives sufficient time for the sattva to contemplate.

The Sāmkhya system considers three types of bodies (Ishwar, 1837, p. 31; Sām. Kār. 40) viz, sukșmaśarīra or liñgaśarīra (subtle body), sthulaśarìra (gross body) and prabhūtaśarira (inanimate body)

Gross body is originally derived from father and mother. The bodies of mountains, tree etc. comes under inanimate body. Subtle body is the combination of eighteen subtle principles. They are intellect, ego sattva, five senses faculties, and five quanta of senses. The subtle body originates first and is aśaktam (unattached) and niyatam (limited). It transmigrates without collecting niryobhogam (Shashtri, 2002, p.34; AH Su.1.26) (experience). It can experience objects only when in conjugation with the gross body. It leaves the gross body at the time of death and regains a new gross body at the time of rebirth. The transmigrating subtle body is loaded with eight features such as merits and demerits, mentioned earlier.

\section{Discussion}

The concept of origin of manas/sattva, as explained by sāmkhya deserves prime importance in the field of Ayurvedic psychotherapy. The dhairya (basic power) and ātmādivijñanam (Acharya, 2002, p.139; CS 2.36) (self-orientation) of the patient are the most essentials to increase the sattva in him to fade away rajas and tamas.

The different systems of science should finally meet at a point, if they are to reach the comparison reveals how far one has travelled in 
search of this reality. Vedas, upanișad, āyurveda, ancient and modern philosophies, religious etc. are in search of finding out what manas is and how to keep it in peace. Manas remains the same in whatever way one studies it so different systems discussing about mind should be same if they are in right direction.

References from vedas denotes very briefly regarding sprintness of manas and its ability to perceive, analyze and stimulate every object and action. In Vedas more emphasis is given on supremacy of Soul in that regard manas being supporter of it. Many a times manas is compared with coach (driver) of chariot (sarìra) which carries the soul and the Chariot is dragged along on the path of the time by the five horses as sense organs. This shows the importance as soul has to travel in the direction where manas wants to carry it. Being controller and conductor of five senses, manas is the only responsible one for knowledge or actions, as horses are useless without coach or driver. Manas being the only active and prime factor considered as the cause of all the blames and boons. Śiva samkalpa sukta of Śukla Yajurveda describes different dimensions of manas. Role of manas in awakeness as well as sleep and dreams has been mentioned in very first verse, which concept is accepted not only by ayurveda but by the modern psychology too. High speed functioning is another attribute and modern scientists. Even today it is well known fact that brain functions are being performed through nervous signals in the form of electric waves which are high velocity. All these concepts are highlighted very briefly in Veda, but don't reveal any clear picture of concept of manas. These concepts are elaborated from the respective point of view by each of the sadarśana according to the aim and goal of every darśana, concept of manas is dealt with.

Concept of manas bears a specific place in Indian Science. Almost all the Indian philosophies have discussed about its existence and importance in phenomenon of cognition. Root of all these philosophies are found in vedic literature where it is said as an instrument of knowledge.

In Sāmkhya darśana, Indriya (jñānendriya, karmendriya and manas) are said to be originated from ahamkāra which means the internal desires of a living creature like listening, hearing etc. are dependent upon development of Indriya.

The thoughts of Sāmkhya darśana are psychological where manas is well described. It mentions that mana does the Sāmkhya kalpanā between two or more padārtha that, the actual matter is that or not. On the base of this Sämkhya Kalpanā, mana is stated as samkalpanātmaka therefore kalpanātmaka is mentioned as guṇa of mana.

Sāmkhya belives manas is necessary for jñāna and karma both because jñānendriya and karmendriya can perform work only when mana is involved. Ācārya Suśruta and Vāgbhata also opine that mana is involved in both jñ̄anātmaka and karmātmaka activities therefore mana is called as ubhayendriya.

Sāmkhya and Vedānta agree that the manas (antahakarana) go out to the object and assume it's form with its mental mode. They suggest that westerns give priority to the object than the subject where as Sāmkhya and Vedānta admit that buddhi (intellect) or antahakarana is an intermediate reality between unconscious matter and conscious spirit.

In Sāmkhya darśana the involvement of manas with lingaśarira is accepted and manas exist as a part of it up to attainment of moksa. This proves that manas is inseparable from its karma in janma-mrtyu paramparā also. Hence its origin is from itself not from any other matter it remains indestructible like lingaśarira. This justify, 
“रुपाद्धि रुपप्रभवः प्रसिद्धः कर्मात्मकानां मनसो मनस्तः। the Caraka's quotation that manas is originated from itself (Acharya, 2002, p.24; CS 1.42).

\section{Conclusion}

There are some similarities between the concepts of Ayurveda and darśana. Āyurveda is “sarvaparisada śāstra”. But, Āyurveda has its own principles. The ultimate goal of both Āyurveda and darśana are same but the way to achieve the goal is different. Sānkhya darśana explains that if sattva increase, mokșa will be achieved and if tamas guna increase punarjanma will be there. Hence, to achieve mokșa one should follow sattvika pravrtti and sattva is one guna of manas.
Sattva is also one synonym of manas. Ayurveda deals with धर्मार्थकाममोक्षाणामारोग्यमूलमुत्तमम् (Acharya, 2002, p. 24, CS 1.42). According to Ayurveda healthy status is required to achieve moksa and darśana explain about tattva jñanna to accomplish moksa.

\section{Bibliography}

Ishwara Krishna, Sankhya Kārika (S. Kār.) of Gaurapada, Reprint, Oxford, London, 1837.

Shri Ram Sharma, Samkhya Darshana (Sām. D.), $1^{\text {st }}$ ed., Vedamata gayatri trust, Haridwara, 2000.

Shashtri Paradakara, Astanga Hrdaya $(A H), 9^{\text {th }}$ ed., Chaukhamba Orientalia, Varanasi, 2002.

Acharya YT, Caraka Samhita (CS.), $7^{\text {th }}$ edition, Chaukhambha Orientalia, Varanasi, 2002. 